\title{
Copyright: A Plea for Empirical Research
}

\author{
I.P.L. Png
}

October 2006

\begin{abstract}
I review empirical research into the economic impact of copyright law. A key difficulty is that there is little systematic measurement of creative output and copying: there are only fragmentary statistics for the various industries. Studies of U.S. copyright registrations provide conflicting results: one shows that small changes in fees have large impacts on renewals, while another shows that many movies and books have long lives. All but one studies find that music piracy - whether conventional or digital - has hurt legitimate CD sales. Studies of extensions of copyright duration yield conflicting results: one focusing on U.S. registrations finds no effect, while a multi-country study finds that extensions are associated with substantial increases in movie production. I conclude with directions for future empirical research.
\end{abstract}

National University of Singapore and IP Academy of Singapore; tel: +65 6516-6807; http://www.comp.nus.edu.sg/ ipng/. This review is based on my keynote address to the Annual Congress of the Society for Economic Research on Copyright Issues (SERCI) in Singapore, June 29-30, 2006. I thank the Executive Committee of SERCI for inviting me to present the lecture, and Congress participants for valuable comments and advice. 
Forthcoming, Review of Economic Research on Copyright Issues.

\section{Introduction}

Copyright law involves a fundamental trade-off between incentives for creators of new work against the benefits from use of existing work for final consumption and as inputs into further creative activity.

"Copyright protection ... trades off the costs of limiting access to a work against the benefits of providing incentives to create the work in the first place. Striking the correct balance between access and incentives is the central problem in copyright law.” (Landes and Posner 1989).

In this trade-off, the "access" to existing work includes use by consumers as well as use by creators of derivative or incremental works. Both research and development and creative activity may be cumulative in the sense that they build on earlier discoveries and creations.

In assessing the trade-off, it is important to consider that copyright law provides protection on three dimensions (Watt 2004): (i) duration - the length of time for which copyright is in force; (ii) depth - which aspects of the creation are protected (generally, copyright law protects the expression but not the idea); and (iii) breadth - the limits of "fair use”, the rights to derivative works, and limits on rental and re-sale. It is also important to consider the costs of tracing and transacting with the copyright owner (Landes and Posner 1989).

There has been a substantial volume of theoretical research into copyright. This has pointed to many empirical issues surrounding the fundamental trade-off. ${ }^{1}$ However, there has been relatively little empirical research, hence major questions remain open.

o "In the formation of copyright policy, the lack of empirical data and the inability to quantify important variables ... preclude precise evaluation of the impact of any significant changes in the degree of copyright protection” (Bard and Kurlantzick (1999) page 3).

o "Perhaps the most pressing area in which the economics of copyright is lacking is in serious empirical studies” (Watt 2004).

In this review, I shall first discuss the barriers to empirical research, then the results of the limited empirical research so far published, and finally, directions for future work. The discussion is organized around three issues:

(i) How to measure creative output and copying;

\footnotetext{
${ }^{1}$ For research into copyright in general, see Landes and Posner (2003), Watt (2004), Varian (2006). See also Boldrin and Levine (2002), Legros (2005), and Liebowitz and Watt (2006).
} 
Forthcoming, Review of Economic Research on Copyright Issues.

(ii) How do changes in copyright law (duration, depth, and breadth) affect the expected earnings of creators of new work?

(iii)What is the creators' elasticity of supply of new work?

\section{Measurement}

The first issue is very basic, viz., the availability of the relevant data, and in particular, data regarding the creation of copyrightable items. The limited availability of such information may well be the single most important reason for the dearth of empirical research into copyright.

The "production" of a copyrightable item has two dimensions - one is the number of different titles, while the other is the volume of each title. The distinction between the two dimensions is important for two reasons. One, production of copyrightable items is subject to a high "first copy cost" relative to the marginal cost of subsequent units. Two, consumers value variety - another copy of the same movie seldom provides as much benefit as a different title. To avoid confusion, I shall use the terms “creation”, “publication”, and “creative activity” rather than "production”.

A subtler issue is that creative activity itself has two dimensions - one is the number of titles, and the other is the quality of each title. Generally, there is no data on the quality of creative activity, so I shall focus on the data available for the number of titles.

Books. The International Publishers Association (IPA) provides annual statistics on titles published in various countries from 1990-1999. The IPA provides complete coverage for only 13 countries, viz., Argentina, Austria, Brazil, Denmark, Finland, France, Germany, Hungary, Latvia, Norway, Sweden, Switzerland, and the U.K. The IPA obtained the data from its national member organizations.

The United Nations Educational, Scientific and Cultural Organization (UNESCO) provides statistics on titles published for a broader set of countries (Canada, Croatia, Cuba, Cyprus, Czech Republic, Denmark, Ecuador, Estonia, Finland, France, Hungary, Iran, Italy, Lithuania, Morocco, Norway, Philippines, Poland, Moldova, Romania, Slovenia, Spain, Switzerland, Macedonia, and Turkey), but for a shorter time period, 1995-1999. The UNESCO website does not disclose the primary sources of the data.

The coverage of the IPA and UNESCO statistics overlap for five countries Denmark, Finland, France, Norway, and Switzerland. For these five countries, the 
Forthcoming, Review of Economic Research on Copyright Issues.

correlation between the IPA and UNESCO numbers over the period 1995-1999 ranged from $-57 \%$ (Norway) to $99.5 \%$ (Hungary), with an average of $32 \%{ }^{2}$

Recorded Music. The International Federation of the Phonographic Industry (IFPI) provides annual statistics of aggregate sales of recorded music (both unit volume and monetary value) for 70 countries. However, IFPI does not report information on the number of titles. The IFPI information is provided by its national member organizations. Accordingly, the coverage of the IFPI statistics depends on the degree to which the various national member organizations provide representative information. For instance, in the case of the United States, “data is collected from RIAA [Recording Industry Association of America] member companies that distribute approximately $84 \%$ of the prerecorded music” (RIAA 2006).

Motion pictures. There are two sources of information about movie creation. One is the Internet Movie Database (IMBb), sponsored by Amazon.com, which proclaims itself to be "Earth’s biggest movie database”. The other is the Film Index International, published by the British Film Institute.

The IMDb encompasses various categories of audio-visual work, including movies, shorts, TV movies, TV series, and videos. IMDb records vary in detail. Most of the information in the IMDb is volunteered by industry members and website visitors.

The Film Index International provides information only about movies. The correlation in the number of movies created across a panel of OECD countries in the Film Index International and IMDb was 93\% (Png and Wang 2006).

Electronic games. The Entertainment Software Association represents publishers of video and computer games that account for more than $90 \%$ of the U.S. entertainment software market. It provides annual statistics of aggregate sales of video and computer games (both unit volume and monetary value) for the United States only. However, ESA does not report information on the number of titles. The data is provided by NPD, a commercial information vendor.

The United Kingdom is the world's third largest market for video and computer games after the United States and Japan. The Entertainment \& Leisure Software Publishers Association (ELSPA) provides annual statistics for the United Kingdom.

\footnotetext{
${ }^{2}$ The International Standard Book Number (ISBN) uniquely identifies every book, but does not provide information about number of titles created (ISBN.org 2006). Specifically, the ISBN is a 10digit number, comprising four parts of variable length, viz., country or region identifier, publisher identifier, title identifier, and a check digit. Each publisher acquires ISBNs from the national ISBN agency in blocks, and uses the numbers in running sequence until exhausted and then applies for a fresh allocation. There is no correspondence between ISBN and year of publication.
} 
Forthcoming, Review of Economic Research on Copyright Issues.

Software. So far as I am aware, there are no publicly available statistics on the creation of software. Indeed, it may well be futile to compile such statistics. The reason is that software differs essentially from the other categories of copyrightable items. First, software is much more heterogeneous - ranging from enterprise systems for thousands of concurrent users to simple single-user online programs. Second, there is relatively more emphasis on new versions of existing titles (eg, Windows, 2.0, 3.0, 98, 2000, ME, XP, etc.) than creation of completely new titles. Moreover, as software is continually "fixed", it is difficult to identify what counts as a new version.

Based on the preceding review, I conclude that what is most urgently needed is accurate statistics of the creation of three categories of copyrightable items - books, recorded music, and electronic games - across countries in recent years. Unfortunately, despite its importance, such work is relatively unglamorous. The best hope is that the relevant industry associations and possibly international organizations such as the World Intellectual Property Organization (WIPO) can be persuaded to collect and publish these statistics.

As with creative activity generally, empirical research into copying depends on reliable measures. By contrast with measurement of the creative activity itself, there is much more public attention to measurement of piracy. (For the purposes of this review, any unauthorized copying is considered to be "piracy”.) Most prominently, the BSA publishes an annual report on piracy of business software with statistics for 97 countries and territories, and the IFPI publishes an annual report on piracy of recorded music with statistics for 73 countries and territories.

Owing to the public policy interest, the Organisation for Economic Co-operation and Development (OECD) and the World Intellectual Property Organization (WIPO) have initiated projects to develop methodologies for measurement of piracy (Olsen 2005). The WIPO project focuses on measurement of copyright piracy (Hui and Png 2005). Hopefully, these efforts will yield internationally-accepted methodologies, that various countries will implement and so produce reliable national statistics on piracy.

\section{Expected Earnings}

Plant (1934) observed that, for most of the $19^{\text {th }}$ century, U.S. copyright law did not provide any protection to British authors, yet British authors received substantial income from U.S. publishers. Remarkably, following Plant's (1934) seminal contribution, almost 70 years elapsed before any further research into the impact of copyright on creators' earnings. 
Forthcoming, Review of Economic Research on Copyright Issues.

Under U.S. law, registration of copyright is not mandatory. However, the law provides an incentive for registration, as the owner must register (or, under the 1976 Copyright Act, apply to register) before the infringement (or within three months of first publication) if the owner seeks statutory damages and attorney fees.

A historical study of registrations with the U.S. Copyright Office provides evidence that the expected value of copyright protection is very low (Landes and Posner 2003). During the period 1910-2000, the registration fee increased several times. Although the fee was quite low (an average of \$20.48 in 2000 dollars over the period), the demand for registrations was price sensitive. Specifically, the elasticity of registrations with respect to the fee ranged from $-0.20( \pm 0.93)$ to $-0.24( \pm 1.34)$. This price sensitivity to even low registration fees suggests that the present value of the future earnings from the copyrighted item was quite small.

Baker and Cunningham (2006) conducted an event study of changes in U.S. copyright law on the stock-market value of companies in copyright-related industries between 1986-98. ${ }^{3}$ They considered both case and statutory law, and found that increases in copyright protection were associated with an average US\$4 - 8.4 million increase in the market value of these companies. ${ }^{4}$

Note, however, that the increase in stock-market value tends to over-state the impact of legal changes on the earnings from a given set of creative activity. The reason is that any increase in market value reflects the increased profit from existing creative work and future infra-marginal creations, as well as the increase in expected profit arising from marginal future creations stimulated by the increased copyright protection.

Next, I review studies that focused on the impact of particular dimensions of copyright law on creators' earnings.

Duration. Rappaport (1998) studied the commercial value in 1998 of movies first copyrighted in the period 1922-1941. He found two trends. First, more recently created movies were more likely to be still played commercially. Specifically, the commercial survival rates were 11\% among movies created in 1926-1928, 40\% among movies created in 1929-1932, and 65\%, among movies created 1933-1941. Second, more recently created movies were of relatively greater commercial value. Specifically, the average commercial

\footnotetext{
${ }^{3}$ Specifically, the industries were SICs 27 (Printing, Publishing and Allied Industries), 73 (Business Services), and 78 (Motion Pictures).

${ }^{4}$ Khong and Khong (2006) conducted a similar study of U.K. companies, and found no significant effect.
} 
Forthcoming, Review of Economic Research on Copyright Issues.

value was \$175,000 among movies created in 1926-1930, \$250,000 among movies created in 1931-1934, and \$400,000 among movies created in 1935-1941.

Landes and Posner (2003) also studied the pattern of renewals of registration with the U.S. Copyright Office during the period 1910-91. Until 1962, renewals were effective for an additional 28 years, while from 1962, the renewal was for 47 years.

Generally, the renewal rate increased from a low of 3\% in 1914 to a high of 22\% in 1991, and the renewal rate was highest for music, middling for books, and lowest for graphic-arts works. Assuming that works were not renewed because the expected future earnings fell below the cost of renewal ( $\$ 10$ plus the time and effort), Landes and Posner (2003) concluded that almost $80 \%$ of copyrighted works had little economic value after the initial term.

By contrast, (Liebowitz and Margolis 2005) studied a sample of 236 titles reviewed by Book Review Digest in the 1920s. Fifty-eight years later, 41\% were still in print.

In assessing the value of copyright protection, it is important to note that, at the point in time where the creator incurs the cost of creative effort, she will not know whether her work will turn into a blockbuster. Hence, copyright, copyright registration, and most importantly, renewal of copyright registration should be valued as real options rather than absolute amounts.

Depth. So far as I am aware, there has been no empirical research into the impact of changes in the depth of copyright protection on creator's earnings. ${ }^{5}$

Breadth. The overwhelming bulk of empirical research into copyright has focused on the impact of the breadth of copyright on creators' earnings, and specifically, the impact of copying. Illegal copying is also called "piracy”. An issue of particular interest is the effect of advances in information and communications technology on copying and the creator's earnings.

In principle, copying could affect creators' earnings positively or negatively. Positive effects include advertising, sampling, and sharing, all of which would stimulate

\footnotetext{
${ }^{5}$ In the case of Baker v. Selden (101 U.S. 99, 1879), Selden published a book describing a new book-keeping system which included sample forms. Baker modified and sold the forms, and was held not to have infringed Selden's copyright. Landes and Posner (1989) explain that the court was correct to limit the depth of copyright protection, as there are limited ways to express the idea of the book-keeping system. Allowing copyright over the forms (an expression) would have essentially provided copyright over the book-keeping system (the idea).
} 
Forthcoming, Review of Economic Research on Copyright Issues.

demand for the legitimate item. The obvious negative effect is the direct substitution of pirated for the legitimate item.

A key innovation in the technology of copying was the photocopying machine. How did that affect the earnings of creators? Liebowitz (1985) observed that, following the widespread adoption of photocopying machines, journal publishers raised subscription rates to libraries relative to rates for individuals. Further, the differential was highest for the most frequently copied journals. By charging discriminatory rates, the publishers could “indirectly appropriate” some of the libraries’ benefit from copying.

With regard to piracy, Hui and Png (2003) studied the experience in 28 countries between 1994-98. The demand for music CDs decreased with piracy, suggesting that “theft” outweighed any positive effects of piracy. Hui and Png (2003) calculated that, in 1998, actual unit losses amounted to about $6.6 \%$ of sales. The actual revenue loss would have been higher as publishers would have raised prices in the absence of piracy. ${ }^{6}$

A relatively recent innovation in the technology of copying is peer-to-peer online file sharing. Owing in part to the landmark Napster and Grokster cases, ${ }^{7}$ online file sharing triggered a veritable cottage industry of empirical research.

The challenge has been to measure the extent of file-sharing and relate it to changes in the sales of music CDs, while taking account of any simultaneity in the relation. Most researchers used various proxies for file-sharing, including the self-reported downloading of music (Peitz and Waelbroeck 2004; Zentner 2006), Internet and broadband penetration (Zentner 2005), Internet penetration (Hong 2004), and Internet usage (Liebowitz 2005). By contrast, Rob and Waldfogel (2004) and Oberholzer-Gee and Strumpf (2005) used direct information on downloading.

While Oberholzer-Gee and Strumpf (2005) found that file-sharing had no impact on music CD sales, all of the other studies concluded that file-sharing caused music CD sales to fall (Liebowitz 2006). ${ }^{8}$ See the Table.

-- Table about here --

\footnotetext{
${ }^{6}$ A related question that has drawn substantial academic interest is what determines piracy. The factors identified include culture (Husted 2000; Marron and Steel 2000), income (Marron and Steel 2000; Rodriguez-Andres 2002), the size of the domestic software industry (Gopal and Sanders 1998), and judicial efficiency (Holm 2003).

7 A\&M Records v. Napster, 239 F.3d 1004 (9th Cir. 2001), and Metro-Goldwyn-Mayer Studios Inc. et al. v. Grokster, Ltd., et al., 125 S. Ct. 2764, 2005 respectively.

${ }^{8}$ Stevans and Sessions (2005) also found that file-sharing reduced CD sales, inferring this from a change in the trend of growth of music CD sales without any information on downloading.
} 
Forthcoming, Review of Economic Research on Copyright Issues.

Another aspect to the breadth of copyright protection is the extent to which the seller of a copyrighted item can control the buyer's commercial use, and specifically, rental and re-sale. In the United States, by the "first sale doctrine", movie studios cannot restrict buyers of pre-recorded videotapes from renting to others. Accordingly, studios have only two choices of pricing - uniform pricing, or indirect discrimination by initially pricing high to capture surplus from video rental stores and then cutting price for "sell through". In the European Union, however, studios can directly discriminate - charging stores different prices for videotapes for rental and for sell through.

Mortimer (2005) estimated the retail demand for rental vis-a-vis sell through videotapes and DVDs, and calculated that direct discrimination would benefit studios and consumers at the expense of retailers in the case of DVDs, but not necessarily in the case of videotapes.

\section{Elasticity of Supply}

Given how changes in copyright law affect the expected returns to creative activity, the next question is how creators respond to changes in earnings. Equivalently, what is their elasticity of supply? For a 1\% increase in earnings, by how much would creators increase their effort, as measured by the number of titles and the quality of each title?

In 2002, the U.S. Supreme Court heard the Eldred case, which challenged the Sonny Bono Copyright Term Extension Act (CTEA). ${ }^{9}$ Seventeen distinguished economists, including five Nobel laureates, filed an amici curiae brief against the CTEA (Akerlof et al. 2002). Based on illustrative calculations, they concluded that, “The CTEA's longer copyright for new works provides at most a very small additional incentive”.

In a trenchant criticism, Liebowitz and Margolis (2005) argued that Akerlof et al. had skirted the central issue: "The present value of additional revenues to authors might be heavily discounted (and small), but this need not imply that the impact of these revenues on the creation of works is small ... The change in the number of new titles depends on the additional reward received by authors and on the elasticity of creation with respect to reward” (pp. 443, 445-446).

So what is this elasticity? Until 1891, U.S. copyright law did not provide any protection to foreign authors. Then, Congress passed the International Copyright Act, which extended copyright protection to foreign authors, and through reciprocal recognition,

${ }^{9}$ Eric Eldred et al., v. John D. Ashcroft, Attorney General, U.S. Supreme Court, No. 01-618. 
Forthcoming, Review of Economic Research on Copyright Issues.

extended international copyright protection to U.S. authors. However, the Act did not have a substantial impact on the number of full-time authors in the United States (Khan 2004). ${ }^{10}$

Png and Wang (2006) studied the impact of extensions of copyright duration on the creation of movies. With retrospective effect from July 1995, the European Union extended the term of copyright over movies to 70 years following the death of the last among the principal director, the screenplay and dialogue authors, and the music composer to die. The extension applied retroactively to any existing work with copyright still in force.

In a sample of 18 countries, Png and Wang (2006) found that the extensions were associated with a $1.80 \%( \pm 1.77 \%)$ to $12.7 \%$ ( $\pm 5.82 \%)$ increase in movie production. An especially compelling result was that the increase in production was higher in countries with lower rates of piracy. The findings were robust to various specifications, including controlling for changes in government funding of movie production. These results suggest that even small increases in creators' earnings can induce substantial increases in movie production.

Separately, Baker and Cunningham (2005) studied the impact of changes in copyright law (both statutory and case-law) on applications for copyright registration. They found that increases in copyright protection were associated with a small positive effect on applications.

In future work, it is important to drill deeper into the incentive effect of copyright law. Specifically, how are increases in future earnings divided among the various parties to creation of new work, for instance, in the case of music, song-writer, performer, and recording studio, and what are the respective incentive effects on each of them? Further, what is the link between creation of new work and registration of copyright?

\section{Concluding Remarks}

I have reviewed various strands of empirical research into copyright law. Clearly, much more work needs to be done. Above, I have pointed to various directions for future work. Here, I will highlight three others.

First, with regard to the fundamental trade-off of intellectual property, there has been no study at all of the "costs of limiting access to a work” (Landes and Posner 1989) - with

10 Towse (2001) observed that that: “Estimates suggest artists' elasticity of supply to arts work is high and so a relatively small financial reward ... can have a greater than proportionate impact on creativity”. From Australian data, Throsby (1996) found that A\$1 (Australian dollar) of income from non-artistic activity displaced $\mathrm{A} \$ 0.14$ of creative income and $\mathrm{A} \$ 0.36$ of arts-related income. 
Forthcoming, Review of Economic Research on Copyright Issues.

regard to both end-use and follow-on creation. Newton (1675) famously declared, "If I have seen further [than certain other men] it is by standing upon the shoulders of giants”. The same applies to the creation of movies, music, and software as well. A key cost of copyright is the impediment to future creators.

Second, we need research into the costs of tracing, transactions, and enforcement involved in the administration of copyright. The magnitude of these costs is crucial to the question of whether copyright should be for fixed term or indefinite (Landes and Posner 2003). In particular, it would be interesting to measure the contribution of collecting societies towards reducing the costs of copyright administration. A study of U.K. copyright cases suggests that bigger companies are relatively more involved in copyright litigation (Mazeh and Rogers 2005). However, is this because of fixed costs of copyright litigation or because bigger companies have more copyrights to enforce?

Third, we need empirical research into the different impact of copyright law on the various categories of creative work. For instance, Landes and Posner (1989) observe that the possible range of popular songs is more limited than of other creative work, and so, support stronger copyright protection for song-writers. To support such differentiation in copyright law, it is necessary to have the appropriate empirical justification. 
Forthcoming, Review of Economic Research on Copyright Issues.

\section{References}

Akerlof, George A., et al., "The Copyright Term Extension Act of 1998: An Economic Analysis”, AEI-Brookings Joint Center for Regulatory Studies, Washington DC, 2002.

Baker, Matthew J., and Brendan M. Cunningham, "Court Decisions and Equity Markets: Estimating the Value of Copyright Protection”, Journal of Law and Economics, forthcoming 2006.

Baker, Matthew J., and Brendan M. Cunningham, "Law and Innovation in Copyright Industries”, U.S. Naval Academy, November 2005.

Bard, Robert L., and Lewis Kurlantzick, Copyright Duration: Term Extension, the European Union and the Making of Copyright Policy, San Francisco: Austin \& Winfield, 1999.

Boldrin, Michele, and David K. Levine, “The Case Against Intellectual Property”, American Economic Review, Papers and Proceedings, Vol. 92 No. 2, May 2002, 209-212.

Business Software Alliance, Third Annual BSA and IDC Global Software Piracy Study, May 2006, http://www.bsa.org/globalstudy/upload/2005\%20Piracy\%20Study\%20\%20Official\%20Version.pdf [Accessed, July 27, 2006].

Corrigan, Ray, and Mark Rogers, “The Economics of Copyright”, World Economics: The Journal of Current Economic Analysis and Policy, Vol. 6 No. 3, July-September 2005, 53-174.

Gopal, Ram D., and G. Lawrence Sanders, "International Software Piracy: Analysis of Key Issues and Impacts”, Information Systems Research, Vol. 9 No. 4, December 1998, 380-397.

Holm, Håkan J. “Can economic theory explain piracy behavior?” Topics in Economic Analysis \& Policy, Vol. 3 No. 1, 2003, Article 5 (http://www.bepress.com/bejeap/topics/vol3/iss1/art5).

Hong, Seung-Hyun, "The Effect of Napster on Recorded Music Sales: Evidence from the Consumer Expenditure Survey”, Stanford Institute for Economic Policy Research, Paper No. 03-018, January 2004.

Hui Kai-Lung, and Ivan Png, "On the Supply of Creative Work: Evidence from the Movies”, American Economic Review, Papers and Proceedings, Vol. 92 No. 2, May 2002, 217-220.

Hui Kai-Lung, and Ivan Png, "Piracy and the Legitimate Demand for Recorded Music", Contributions to Economic Analysis \& Policy, Vol. 2 No. 1, 2003, Article 11.

Hui Kai-Lung, and Ivan Png, "Measuring Piracy of IP-Protected Goods: A Methodology”, World Intellectual Property Organization: Working Group of Experts on Developing a Methodology for Measuring Copyright Piracy, November 1-4, 2005, http://www.econaa.com/resources/methodology_piracy_rate_sector.pdf [Accessed, July 27, 2006].

Hurt, Robert M., and Robert M. Schuchman, “The Economic Rationale of Copyright”, American Economic Review, Vol. 56, No. 1/2, March 1966, 421-432.

Husted, Bryan W. "The Impact of National Culture on Software Piracy”, Journal of Business Ethics, Vol. 26 No. 3, August 2000, 197-211.

IFPI (International Federation of the Phonographic Industry), The Recording Industry: Commercial Piracy Report, 2004, London.

ISBN.org, [Accessed, March 22, 2006]

Khan, B. Zorina, "Does Copyright Piracy Pay? The Effects of U.S. International Copyright Laws on the Market for Books, 1790-1920”, Working Paper 10271, National Bureau of Economic Research, Cambridge, January 2004.

Khong, W.L. Roy, and Dennis Khong, “Does United Kingdom’s Stock Market Respond to Copyright Term Extension”, Faculty of Business and Law, Multimedia University, Malaysia. 
Forthcoming, Review of Economic Research on Copyright Issues.

Landes, William M., and Richard A. Posner. “An Economic Analysis of Copyright Law,” Journal of Legal Studies, Vol. 18 No. 2, June 1989, 325-363.

Landes, William M., and Richard A. Posner, The Economic Structure of Intellectual Property Law, Cambridge, MA: Belknap Press, 2003.

Legros Patrick, “Art and the Internet: Blessing the Curse?” NAJ Economics, Vol. 10, March 21, 2005.

Liebowitz, Stan J., “Copying and Indirect Appropriability: Photocopying of Journals”, Journal of Political Economy, Vol. 93 No. 5, October 1985, 945-957.

Liebowitz, Stan J., “Testing File-Sharing’s Impact by Examining Record Sales in Cities”, Working Paper, School of Management, University of Texas at Dallas, September 2005.

Liebowitz, Stan J., "Economists Examine File-Sharing and Music Sales”, in Gerhard Illing and Martin Peitz, Eds., Industrial Organization and the Digital Economy, Cambridge: MIT Press, 2006.

Liebowitz, Stan J., and Stephen Margolis, "Seventeen Famous Economists Weigh in on Copyright: The Role of Theory, Empirics, and Network Effects”, Harvard Journal of Law \& Technology, Vol. 18, No. 2, Spring 2005, 435-457.

Liebowitz, Stan J., and Richard Watt, "How to Best Ensure Remuneration for Creators in the Market for Music? Copyright and its Alternatives”, SERCI WPS01, Society for Economic Research in Copyright Issues, 2006.

Marron, Donald B., and David G. Steel "Which Countries Protect Intellectual Property? The Case of Software Piracy”, Economic Inquiry, Vol. 38 No. 2, April 2000, 159-174.

Mazeh, Yoav, and Mark Rogers, "The Extent and Significance of Copyright Cases: An Analysis of Large UK Firms”, Oxford Intellectual Property Research Centre, December 2005.

Mortimer, Julie Holland, "Price Discrimination, Copyright Law and Technological Innovation: Evidence from the Introduction of DVDs”, Working Paper No. W11676, National Bureau of Economic Research, Cambridge, October 2005.

Newton, Isaac, Letter to Robert Hooke, February 5, 1675.

Oberholzer-Gee, Felix, and Koleman Strumpf, “The Effect of File Sharing on Record Sales: An Empirical Analysis”, Harvard Business School and UNC Chapel Hill, June 2005.

Olsen, Karsten, “Counterfeiting and Piracy: Measurement Issues”, WIPO/OECD Expert Meeting on Measurement and Statistical Issues, Geneva, October 17-18, 2005.

Peitz, Martin, and Patrick Waelbroeck, "The Effect Of Internet Piracy On Music Sales: CrossSection Evidence”, Review of Economic Research on Copyright Issues, Vol. 1 No. 2, December 2004, 71-79.

Plant, Arnold, “The Economic Aspects of Copyright”, Economica, Vol. 1 No. 2, May 1934, 167-195.

Png, I.P.L., and Qiu-hong Wang, "Copyright Duration and the Supply of Creative Work”, Department of Information Systems, National University of Singapore, April 2006.

Rappaport, Edward, “Copyright Term Extension: Estimating the Economic Values”, Washington, DC: Congressional Research Service, May 11, 1998, http://countingcalifornia.cdlib.org/crs/pdf/98-144.pdf .

RIAA (Recording Industry Association of America), "yearend report”, http://www.riaa.com/news/marketingdata/yearend.asp [Accessed, March 22, 2006].

Rob, Rafael, and Joel Waldfogel, "Piracy on the High C's: Music Downloading, Sales Displacement, and Social Welfare in a Sample of College Students”, Journal of Law and Economics, Vol. 49, April 2006, 29-62. 
Forthcoming, Review of Economic Research on Copyright Issues.

Rodriguez-Andres, “The European Software Piracy: An Empirical Application”, Department of Economics, University of Southern Denmark, March 2002.

Stevans, Lonnie K., and David N. Sessions, "An Empirical Investigation Into the Effect of Music Downloading on the Consumer Expenditure of Recorded Music: A Time Series Approach", Journal of Consumer Policy, Vol. 28, 2005, 311-324.

Throsby, David, “Disaggregated earnings functions for artists”, Chapter 13 in Victor A. Ginsburgh and Pierre-Michel Menger, eds., Essays in the economics of the arts, New York: Elsevier, 1996.

Towse, Ruth, "Partly for the Money: Rewards and Incentives to Artists”, Kyklos, Vol. 54 No. 2/3, May 2001, 473-490.

Varian, Hal, “Copying and Copyright”, Journal of Economic Perspectives, Vol. 19, No. 2, Spring 2005, 121-138.

Watt, Richard, "The Past and the Future of the Economics of Copyright”, Review of Economic Research on Copyright Issues, Vol. 1 No. 1, June 2004, 151-171.

Zentner, Alejandro, "File Sharing and International Sales of Copyrighted Music: An Empirical Analysis with a Panel of Countries", Topics in Economic Analysis \& Policy, Vol. 5: No. 1, Article 21, 2005.

Zentner, Alejandro, "Measuring the Effect of File Sharing on Music Purchases", Journal of Law and Economics, Vol. 49, April 2006, 63-90. 
Forthcoming, Review of Economic Research on Copyright Issues.

Table: Peer-to-peer file sharing and music CD sales

\begin{tabular}{|c|c|c|}
\hline Study & Period & Sales impact \\
\hline Hong (2004) & 2000 & U.S. $-7.8 \%$ \\
\hline Liebowitz (2005) & 1998-2003 & U.S. cities: $-3.2 \%$ \\
\hline Peitz and Waldbroeck (2004) & 2000-01 & $\begin{array}{l}\text { Worldwide: }-11 \% \\
\text { U.S.: }-12 \%\end{array}$ \\
\hline Rob and Waldfogel (2004) & 2003/04 & $\begin{array}{l}\text { U.S. university students: } \\
-9 \%\end{array}$ \\
\hline Zentner (2005) & $\begin{array}{l}\text { 1997/98- } \\
2000 / 01\end{array}$ & 56 countries: $-6.6 \%$ \\
\hline Zentner (2006) & 2001 & $\begin{array}{l}7 \text { European countries: } \\
-7.8 \%\end{array}$ \\
\hline Oberholzer-Gee and Strumpf (2005) & Fall 2002 & Not significant \\
\hline
\end{tabular}

